\title{
Impact of gender inequality on economic growth: A study of developing countries
}

\author{
Poulomi Mukherjee $^{1}$, Dr. Isita Mukhopadhyay ${ }^{2}$ \\ ${ }^{1}$ Research Scholar, Department of Economics, University of Calcutta \\ ${ }^{2}$ Professor, Department of Economics, University of Calcutta
}

\begin{abstract}
Using cross country regressions, this paper investigates how gender inequality in education and labour force participation affect economic growth. The study concentrates on the contemporary data of 61 developing countries of Africa, Asia and Latin America over the year 2010. Such inequality is found to have an effect on economic growth. The result suggests that gender inequality in education adversely affects economic growth, whereas gender inequality in labour force participation has a positive impact on it.
\end{abstract}

Key words: Economic Growth, Gender inequality, Education, Gender inequality in labour force participation.

\section{Introduction}

Growth theory suggests that economic growth depends on the accumulation of economic (including human) factors, and the return on these assets, which in turn depend on technological progress, the efficiency with which assets are being used, and the institutional frameworks of production. The different strands of the growth literature all agree on these factors but differ in the way these factors interact to generate sustainable growth. Gender issues will naturally come into play in the way all of these factors influence economic growth.

There may be gender differences in the way human assets are being generated and accumulated, and gender issues may also play a role in the way physical assets (including land but also other physical capital) are being maintained and augmented. In addition, gender issues may play a role in influencing technological progress, as well as the efficiency with which assets are being used to produce incomes. Lastly, gender issues may influence institutions, both public and private, which can help or hinder the efficiency of resource use.

The relationship between economic growth \& gender discrimination is the most debated concept.

Feminist scholar maintains that gender is an important macroeconomic variable \& it can affect economic growth. Gender inequality refers to unequal treatment of individuals based on their gender. It arises from difference in socially constructed gender roles as well as biological structure. It is not constant over time or across country, rather it is a variable factor. Gender inequality is a multidimensional term including economic, cultural and social dimensions alike. Here, we confine our study to two important aspects that serve the purposes of our analysis. The first is equal right to education. This right is an essential condition of labour market equality, but is not sufficient one. If women or men are discriminated against in terms of access to education, society's human capital is not rationally being used. The second is equal right (and opportunity) to work in the market. At present there are major differences in the levels of labour force participation between women and men (Löfström, 2008), because women have to do both housework and work in the market.

Traditionally, women have been expected to perform most of the work in the home as a matter of course, regardless of which partner is most suited to the task. This traditional attitude is still an important explanation of the differences in women's labour participation (considerably greater than men's) found in different countries. Another argument is that gender gaps in employment impose a serious distortion on the economy. They artificially reduce the pool of talent from which employers can draw, thereby reducing the average ability of the workforce (Klasen and Lamanna 2003). Gender inequality can affect economic growth in various ways. Hence this study concentrates on the impact of gender inequality in education and labour force participation on economic growth.

\section{Review of past literature}

Various studies have been done so far in different countries on impact of gender inequality on economic growth. Some of the significant studies are summarized below:- 


\begin{tabular}{|c|c|c|}
\hline Name and Author & Objectives & Findings \\
\hline $\begin{array}{l}\text { Forsythe, N. and } \\
\text { Korzeniewicz, R. P. (2000), } \\
\text { Gender Inequality and } \\
\text { Economic Growth: A } \\
\text { Longitudinal Evaluation }\end{array}$ & $\begin{array}{l}\text { To find out the relationship } \\
\text { between economic growth } \\
\text { and gender inequality }\end{array}$ & $\begin{array}{l}\text { 1. Economic development } \\
\text { has a significant positive } \\
\text { impact on the status of } \\
\text { women. } \\
\text { 2. There is a curvilinear } \\
\text { relationship } \\
\text { growth and getween } \\
\text { inequality. }\end{array}$ \\
\hline $\begin{array}{l}\text { Klasen, S. (2000), Does } \\
\text { Gender Inequality Reduce } \\
\text { Growth and Development? } \\
\text { Evidence from Cross- } \\
\text { Country Regressions }\end{array}$ & $\begin{array}{l}\text { To find out the instrumental } \\
\text { impact of gender inequality } \\
\text { in education on economic } \\
\text { growth }\end{array}$ & $\begin{array}{l}\text { 1. Female-male ratio of } \\
\text { schooling achievement as } \\
\text { well as the female-male } \\
\text { ratio of expansions in the } \\
\text { level of schooling has a } \\
\text { significant positive impact } \\
\text { on economic growth. } \\
2 \text {. Reduced gender } \\
\text { inequality in education } \\
\text { leads to higher investment } \\
\text { rate which in turn is related } \\
\text { to higher labour force } \\
\text { growth. } \\
\text { 3. Growth in the female } \\
\text { share in working age } \\
\text { population has a positive \& } \\
\text { significant impact on } \\
\text { economic growth. }\end{array}$ \\
\hline $\begin{array}{l}\text { Lagerlöf, N. (1999). Gender } \\
\text { Inequality, Fertility, and } \\
\text { Growth }\end{array}$ & $\begin{array}{l}\text { To find out the impact of } \\
\text { gender gap in education on } \\
\text { economic growth. }\end{array}$ & $\begin{array}{l}\text { Gender inequality in } \\
\text { education leads to higher } \\
\text { fertility, lower economic } \\
\text { growth and creating a } \\
\text { poverty trap in the } \\
\text { economy. }\end{array}$ \\
\hline $\begin{array}{l}\text { Seguino, S. (2000), Gender } \\
\text { Inequality and Economic } \\
\text { Growth: A Cross Country } \\
\text { Analysis }\end{array}$ & $\begin{array}{l}\text { To find out whether gender } \\
\text { inequality which } \\
\text { contributes to women's } \\
\text { relatively lower wages was } \\
\text { a stimulus to economic } \\
\text { growth through its impact } \\
\text { on semi industrialized } \\
\text { export oriented sector. }\end{array}$ & $\begin{array}{l}\text { GDP growth is positively } \\
\text { related to the gender } \\
\text { inequality. }\end{array}$ \\
\hline $\begin{array}{l}\text { Çagatay, N. and Ozler, S. } \\
\text { (1995), Feminization of the } \\
\text { Labor Force: The Effects of } \\
\text { Long-Term Development } \\
\text { and Structural Adjustment }\end{array}$ & $\begin{array}{l}\text { To analyze the relationship } \\
\text { between women's share of } \\
\text { the labour force and the } \\
\text { process of long term } \\
\text { economic development and } \\
\text { short term macroeconomic } \\
\text { changes associated with } \\
\text { structural adjustment } \\
\text { policy. }\end{array}$ & $\begin{array}{l}\text { 1. There is a robust } \\
\text { relationship between } \\
\text { women's share of labour } \\
\text { force \& the level of } \\
\text { economic development. } \\
\text { 2. Demographic as well as } \\
\text { cultural factors play a role } \\
\text { in determining the degree of } \\
\text { feminization of the labour } \\
\text { force. }\end{array}$ \\
\hline $\begin{array}{l}\text { Fatima, G. (2010), Female } \\
\text { Education as a Determinant } \\
\text { of Economic Growth- A } \\
\text { Case Study of Pakistan }\end{array}$ & $\begin{array}{l}\text { 1. Examine the causes of } \\
\text { gender inequality in } \\
\text { education. } \\
\text { 2. Investigate how gender } \\
\text { inequality in education }\end{array}$ & $\begin{array}{l}\text { 1. There is no strong } \\
\text { relationship between female } \\
\text { education \& economic } \\
\text { growth. } \\
\text { 2. The critical link between }\end{array}$ \\
\hline
\end{tabular}




\begin{tabular}{|c|c|c|}
\hline & $\begin{array}{l}\text { impacts economic growth } \\
\text { and development. and } \\
\text { 3. Draw suitable policy } \\
\text { implications for minimizing } \\
\text { the gender-based adverse } \\
\text { effects on economic } \\
\text { development. }\end{array}$ & $\begin{array}{l}\text { status of women in society, } \\
\text { particularly literacy level \& a } \\
\text { nation's economic growth is } \\
\text { well understood. } \\
\text { 3. The low socio-economic } \\
\text { status of women in } \\
\text { Pakistan is beginning to be } \\
\text { recognized as a potentially } \\
\text { significant drag on the } \\
\text { country's growth. }\end{array}$ \\
\hline $\begin{array}{l}\text { Rasouli, Z. (2013). } \\
\text { Economic growth \& } \\
\text { Gender inequality in India }\end{array}$ & $\begin{array}{l}\text { To find out how and to what } \\
\text { extent does engagement } \\
\text { with global economy in } \\
\text { India increased gender } \\
\text { inequality. }\end{array}$ & $\begin{array}{l}\text { Indian economic growth } \\
\text { does not have a big impact } \\
\text { on increased gender } \\
\text { inequality. }\end{array}$ \\
\hline
\end{tabular}

Although there is vast literature integrating gender inequality and economic growth but the studies could not capture the dynamicity of scenario in recent ages. Hence this study concentrates on the impact of gender inequality in education and labour force participation on economic growth.

\section{The Model, Data and Methodology}

The study considers contemporary data of 61 developing countries of Afro Asia and Latin America for the year 2010 following the income wise classification of World Development Report 2012. Contemporary data collected from World Bank, World Development Indicator 2012 is used for investigating departure from earlier studies. In WDR 2012 following income wise classification there are 90 developing countries in the globe from which 61 countries are selected because complete matrix of all variables (female male ratio in primary enrollment, female male ratio in secondary enrollment, female male ratio in labour participation, openness as regional dummy) is there for 61 countries. Developing countries are characterised by low level of income, high population growth resulting low standard of living.

To estimate the impact of gender inequality on economic growth data records are collected from different units. Such as data on female male ratio in primary, secondary education and female male ratio in labour force participation, per capita gross domestic product are collected from World Bank, (world development indicator), data on openness is also collected from World Bank (world development indicator).

This study follows the structure of Klasen $(2000,2002)$ model. From the literature we find that there are several variables which are taken for their analysis. On the basis of this literature the study considers the following variables - Female male ratio in primary enrollment, Female male ratio in secondary enrollment,

Female male ratio in labour participation rate, Openness (regional dummy). On the basis of this variables the equations of the model be presented below -

$$
\begin{aligned}
& \mathrm{g}=\alpha_{1}+\beta_{11} \text { fmpe }+\beta_{21} \text { fmlpr }+\beta_{31} \text { open } \\
& \mathrm{g}=\alpha_{2}+\beta_{12} \text { fmse }+\beta_{22} \mathrm{fmlpr}+\beta_{32} \text { open }
\end{aligned}
$$

Where $\mathrm{G}=$ Per capita gross domestic product or GDP per capita, PPP (current international \$)

FMPE $=$ Ratio of female to male primary enrollment (\%).

FMSE $=$ Ratio of female to male secondary enrollment $(\%)$.

FMLPR $=$ Ratio of female to male labor participation rate $(\%)$

OPEN= Openness is a regional dummy. It is calculated by using the following formula

OPEN $=\{($ export/import $) * 100\}$

Each "small" letter implies the logarithm of the variable presented in "capital" letter.

$\beta_{11}, \beta_{21}, \beta_{31}, \beta_{12}, \beta_{22}, \beta_{32}$ represent respective parameters.

$\alpha_{1}, \alpha_{2}$ represent the intercept terms

\section{Descriptive Statistics:}

This section explores the data and describes the situation. Consider 61 developing countries together for the study of assessing the impact of gender inequality in education (measured by female male ratio in primary and secondary enrollment) and labour participation (measured by female male ratio in labour participation) on economic growth (measured by GDP per capita). According to the data female male ratio in primary education follows more or less linear pattern with the rise in GDP per capita that means this ratio remains the same with rise in GDP per capita as presented in following figure-1 where GDP per capita is 
measured along the horizontal axis and female male ratio in primary education is measured along the vertical axis:

Figure -1

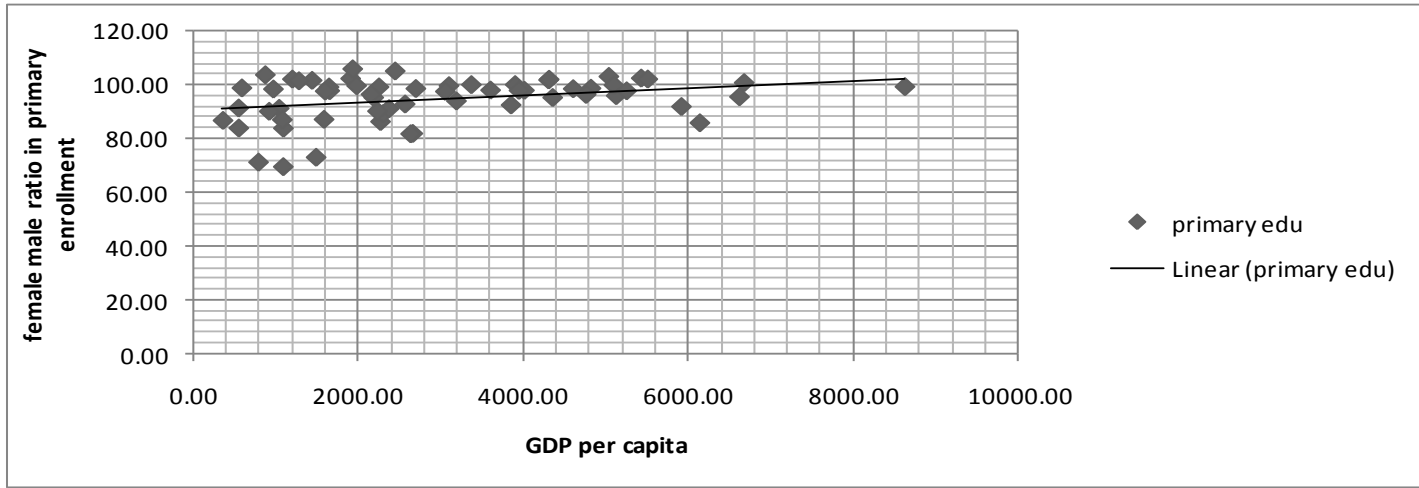

In the case of secondary education figure-2 (consider GDP per capita along the horizontal axis and female male ratio in secondary education is measured along the vertical axis) shows that with the rise in GDP per capita female male ratio in secondary education also improves but there is an outlier in the case of Lesotho where GDP per capita is not so high but the female male ratio in secondary education is quite impressive. Figure-9 is represented below:

Figure -2

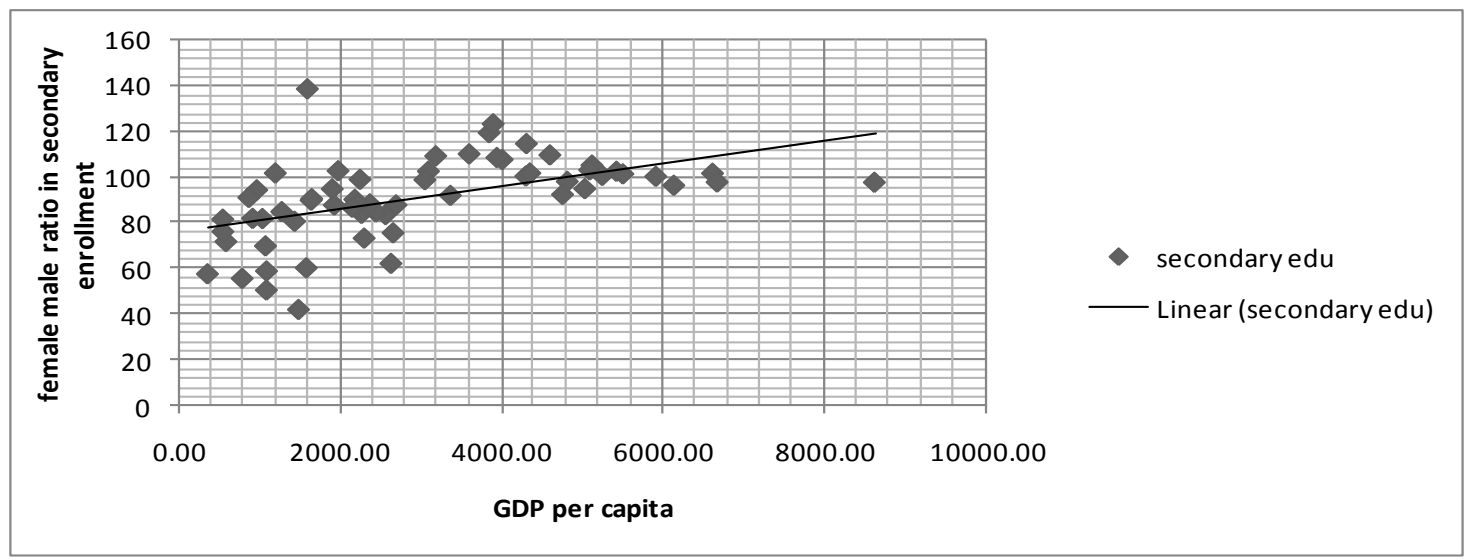

Now to get a clear picture of the level of education and GDP per capita this study first rank the countries according to their GDP per capita. Ranking is done according to the descending order of magnitude that is rank 1 is given to the country having maximum GDP per capita value and so on. Data shows that as rank increases from 1 to 61 then female male ratio in primary enrollment raises more compared to secondary education except for the country Lesotho. Figure-3 represents this study by a segmented bar is given below:

Figure -3

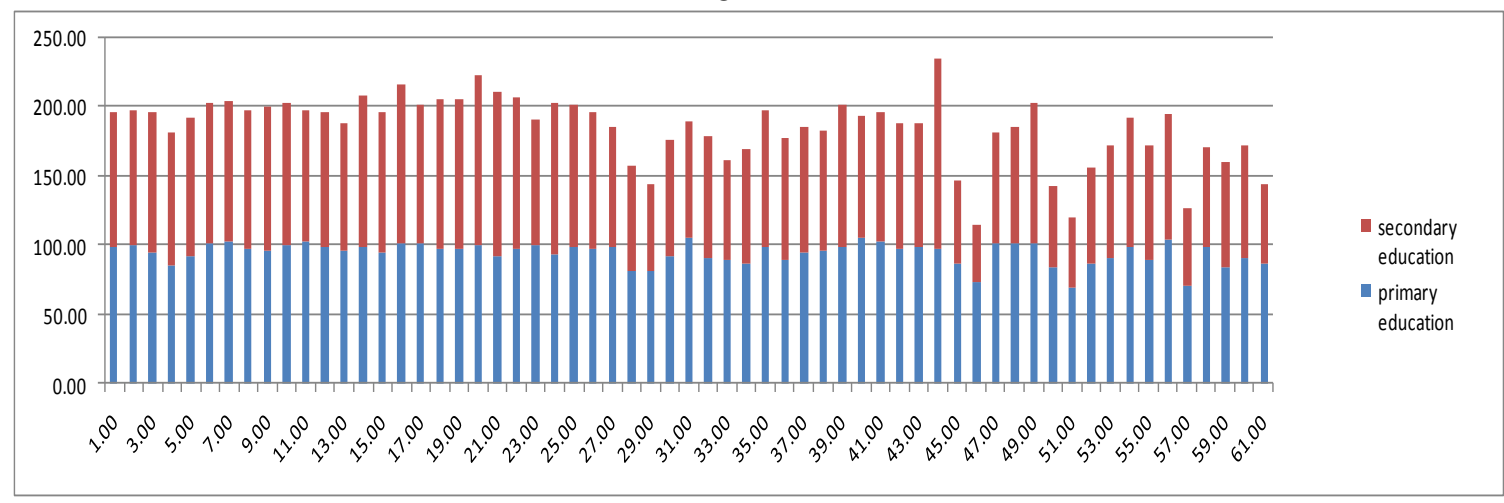


Above figure shows that country which ranks 1 has almost equal ratio of female male in primary and secondary enrollment where as the country which ranks 61 has a higher ratio of female male in primary enrollment compared to secondary enrollment.

Now consider the relationship between female male ratio in labour force participation and GDP per capita. Figure-3 shows that the relationship is very fluctuating in nature. That means diagram considers this relation is very scattered as presented below:

Figure -4

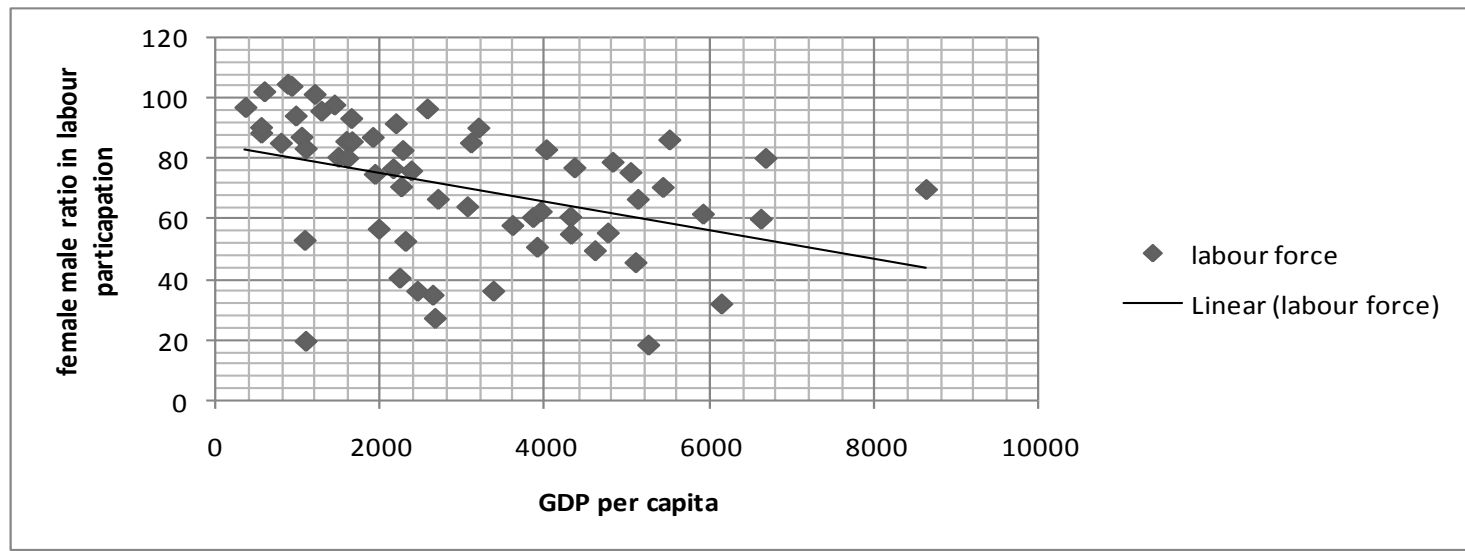

This fluctuation occur either due to the fluctuation in female labour participation or male labour participation or due to both the factors. To find out the actual source of fluctuation the study considers a diagrammatic representation of female labour participation and male labour participation with respect to GDP per capita as shown below:

Figure -5

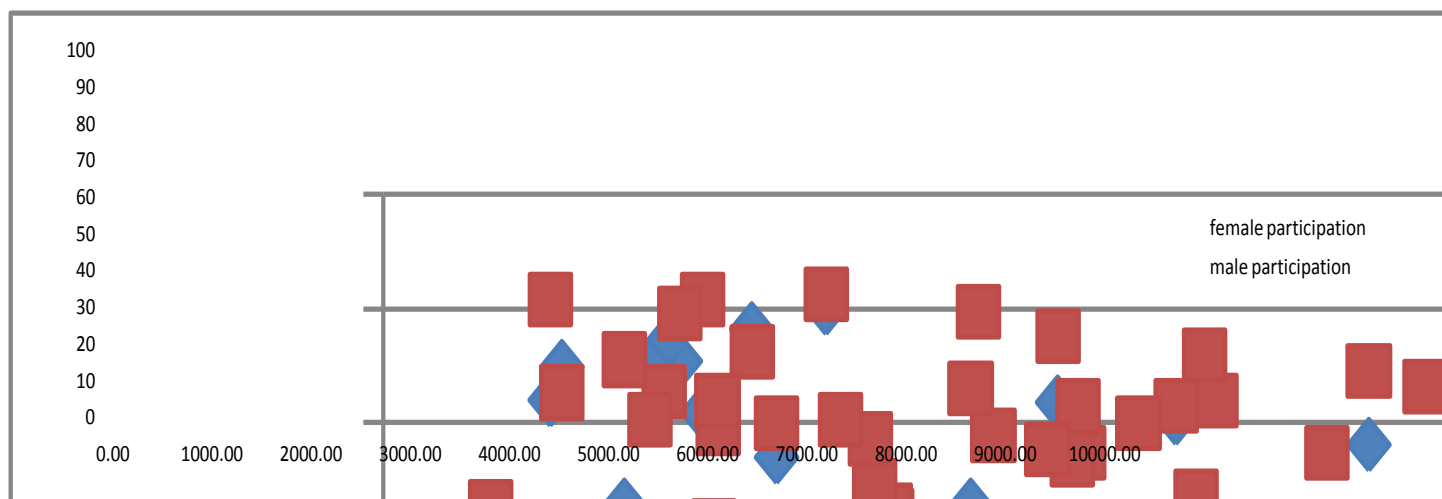

Figure-5 indicates that female labour force participation is the sole reason for that fluctuation because with the rise in GDP per capita male labour force participation rate almost remains the same but for most of the countries with lower GDP per capita has the higher female labour force participation rate. The reason may be that due to the huge burden of poverty they are engaged in the labour force for bear subsistence.

Intuition:

I. GDP share is maximized in Asian countries followed by Africa. In Asia GDP has a very small contribution for primary enrollment but in case of secondary education GDP has a huge contribution.

II. In case of labour force participation rates both for female and male GDP has a greater contribution for the African countries, where Asia gets a restively small share in both respect.

III. In case of primary education the trend line is upward rising like secondary education but for primary education the trend line is flatter compared to secondary education where the study has got a steeper trend line.

IV. Labour force participation with respect to GDP per capita shows a negatively sloped trend line

\section{Methodology}


Simple OLS regression has been done to estimate the model. Ordinary least squares (OLS) or linear least squares are a method for estimating the unknown parameters in a linear regression model. This method minimizes the sum of squared vertical distances between the observed responses in the dataset and the responses predicted by the linear approximation. The resulting estimator can be expressed by a simple formula, especially in the case of a single regressor on the right-hand side. The OLS estimator is consistent when the regressors are exogenous and there is no perfect multicollinearity, and optimal in the class of linear unbiased estimators when the errors are homoscedastic and serially uncorrelated.

To test the overall significance of the regression the study considers ANOVA (Analysis of Variance) technique. Both the analysis of variance and regression analysis have as their objective the determination of the various factors which cause variation of the dependent variable.

\section{Result and Analysis}

The result obtained by regression indicates that gender discrimination in primary and secondary education has a positive and significant impact on economic growth but gender discrimination in labour force participation does not provide positive impact on economic growth rather data indicates that there is a significantly negative impact of gender equality of labour force participation on economic growth. Result can be summarized by the following tables -

Table - 1: Regression table without regional dummy

\begin{tabular}{|l|c|c|}
\hline \multicolumn{1}{|c|}{ Variables } & Co-efficient & t-value \\
\hline Fmpe & 3.89 & $4.48^{* * *}$ \\
\hline Fmlpr & -0.9 & $-4.5^{* * * *}$ \\
\hline
\end{tabular}

*** Significant at $1 \%$ level of significance

Table -1 indicates that female male ratio in primary education has a positive and significant impact on economic growth. This ratio indicates female primary enrollment compared to male enrollment, it is nothing but the indicator gender equality or on the other hand it is an indicator of gender inequality in education. If this ratio tends to 1 or $100 \%$ that means there is no gender inequality that is women and men have an equal opportunity to be educated. That is the reason behind the selection of this ratio as an indicator of gender inequality in education. Similar logic is applicable for selecting female male ratio in labour participation. Result indicates that it has a negative and significant impact on economic growth when there is no regional dummy.

Table - 2: Regression table without regional dummy

\begin{tabular}{|l|c|c|}
\hline \multicolumn{1}{|c|}{ Variables } & Co-efficient & t-value \\
\hline Fmse & 1.97 & $6.34 * * *$ \\
\hline Fmlpr & -0.71 & $-4.09 * * *$ \\
\hline
\end{tabular}

*** Significant at $1 \%$ level of significance

Above table shows that female male ratio in secondary enrollment is positively and significantly related to economic growth. In case of labour force participation the effect negative but significant. Now consider regional dummy in the above model and the regression.

Table - 3: Regression table with regional dummy

\begin{tabular}{|l|c|c|c|}
\hline \multicolumn{1}{|c|}{ ariables } & Co-efficient & \multicolumn{2}{|c|}{ t-value } \\
\hline Fmpe & 3.41 & \multicolumn{2}{|c|}{$4.30^{* * *}$} \\
\hline Fmlpr & -0.76 & \multicolumn{2}{|c|}{$-4.12^{* * *}$} \\
\hline Open & 0.60 & $3.76^{* * *}$ \\
\hline
\end{tabular}

*** Significant at $1 \%$ level of significance

Table-3 implies that openness which indicates regional dummy has a positive and significant impact on economic growth.

Table - 4: Regression table with regional dummy

\begin{tabular}{|l|c|c|}
\hline \multicolumn{1}{|c|}{ ariables } & Co-efficient & t-value \\
\hline Fmse & 1.78 & $6.34 * *$ \\
\hline Fmlpr & -0.60 & $-3.82^{* * *}$ \\
\hline Open & 0.56 & $3.99 * * *$ \\
\hline
\end{tabular}

*** Significant at $1 \%$ level of significance 
Table -4 indicates the same impact of openness on economic growth as shown in the previous table.

Table - 5: Correlation table

\begin{tabular}{|l|l|}
\hline \multicolumn{1}{|c|}{ Correlation between variables } & Values \\
\hline Openness and labour force & 0.16 \\
\hline Openness and primary education & 0.11 \\
\hline Openness and secondary education & 0.16 \\
\hline
\end{tabular}

Normally openness is correlated with labour force participation, primary and secondary enrollment but in case of 2010 data value of correlations are almost negligible. This implies there is no multicollinearity among the data that's why we can apply simple OLS regression.

To test the overall significance ANOVA technique is considered where null hypothesis are $\quad \mathrm{H}_{0}$ : i. $\beta_{11}=$ $\beta_{21}=\beta_{31}=0$

ii. $\beta_{12}=\beta_{22}=\beta_{32}=0$

Against alternative $\mathrm{H}_{\mathrm{A}}$ : not all $\beta$ 's are simultaneously equal to zero

The values are represented below in a table form -

Table - 6 ANOVA

\begin{tabular}{|l|c|}
\hline \multicolumn{1}{|c|}{ Regressions } & F-statistics \\
\hline Regression-1 with regional dummy & $18.09 * * *$ \\
\hline Regression-2 with regional dummy & $28.78 * * *$ \\
\hline Regression-1 without regional dummy & $16.34 * * *$ \\
\hline Regression-2 without regional dummy & $28.001 * * *$ \\
\hline
\end{tabular}

*** Significant at $1 \%$ level of significance

Table- 6 represents the $\mathrm{F}$ value of regression-1 and regression- 2 to test the above hypothesis. Now result shows that calculated value of $\mathrm{F}>\mathrm{F}_{3,57}$ at $1 \%$ level of significance (in case of with regional dummy) and also calculated value of $\mathrm{F}>\mathrm{F}_{2,58}$ at $1 \%$ level of significance (in case of without regional dummy). Both the results imply null hypothesis are rejected.

Table -7: R-square table

\begin{tabular}{|l|c|c|}
\hline \multicolumn{1}{|c|}{ Regressions } & R-square & Adjusted R-square \\
\hline Regression-1 with regional dummy & 0.49 & 0.46 \\
\hline Regression-2 with regional dummy & 0.60 & 0.58 \\
\hline Regression-1 without regional dummy & 0.36 & 0.34 \\
\hline Regression-2without regional dummy & 0.49 & 0.47 \\
\hline
\end{tabular}

R-square and adjusted R-square help to understand the goodness of fit of the estimated model and also help to assess the relevance of explanatory variables in explaining the variation in dependent variable of our model. Table-7 shows that in case of $1^{\text {st }}$ regression explanatory variables are able to explain $49 \%$ of the variation in dependent variable and in case of $2^{\text {nd }}$ regression explanatory variables are able to $60 \%$ of the variation in dependent variable.

Summary of observations:

- Female male ratio in primary enrollment has a positive and significant impact on economic growth.

- Female male ratio in secondary enrollment has a positive and significant impact on economic growth.

- Female male ratio in labour participation rate has a negative and significant impact on economic growth.

- Openness (indicator of regional dummy) has a positive and significant impact on economic growth.

Primary and secondary enrollment:

\section{Analysis}

Result shows that the co-efficient of female male ratio in both primary and secondary enrollment are positive and their $t$ values are positive and significant at $1 \%$ level of significance that is they positively and significantly affect economic growth. According to Todaro, 2007 female education is important for the following four reasons -

i. "Women's education has the higher rate of return in than that of men.

ii. Rising women's education on one hand increases productivity in the fields and on the other $\mathrm{h}$ and also results in greater labor force, lower fertility and improved child health and nutrition.

iii. More educated mother lead to multiplier effects on the quality of a nation's human resources for many generations to come and also lead to the improvement in child health and nutrition. 
iv. Women bear a disproportionate burden of poverty and landlessness that permeates developing societies, that's why any significant improvement in their role via education can have an important impact on breaking vicious cycle of poverty and inadequate schooling".

As the ratio of female male in primary as well as secondary education increases that means female become more educated compared to male then the gap between male and female education reduces which indicates gender equality. Result indicates that female male ratio in both primary and secondary educations have positive and significant impact on economic growth. The implication is that increase in female male ratio in both primary and secondary enrollments raise GDP per capita or we can say that if this ratio decreases then it reduces GDP per capita. In other words if there is gender discrimination with respect to education then economic growth is adversely affected.

Further if female become more educated then their capacity to adopt better technology increases which leads to their skill development. Then they can apply better technology and efficiently utilize the society's scarce resources, which in turn leads to economic growth.

One thing should be noted that the $\mathrm{t}$ value is higher for secondary education as compared to primary education. This is because with the rise in education level the contribution towards economic growth also increases.

\section{Labour force participation:}

Result indicates that ratio of female male in labour force participation has a negative and significant impact on economic growth. This is a challenge to the existing literatures which implies a $\mathrm{U}$ shape relationship between economic growth and labour force participation (Cagatay \& Ozler, 1995). According to the result as the ratio of female male in labour participation increases then GDP per capita reduces, on the other hand when this ratio decreases that means if there is gender bias in labour participation then it leads to economic growth.

Now this ratio changes due to two factors either female participation changes or male participation changes. From figure- 5 it is clear that this change occurs due to the $1^{\text {st }}$ factor. The reason behind this is that women are the vulnerable part of the society. They are engaged in the unpaid domestic work which is totally excluded from national income accounting identity. Unpaid work is perhaps the biggest contribution that women make to the economy. This includes housework, raising children, caring for the sick or elderly, making clothes, preserving food, keeping hens, growing fruit and vegetables, household maintenance and small construction projects. Without the unpaid work done largely by women in the home, family members could not spend as much time at paid work outside the home. Unpaid work has been described as 'the invisible infrastructure which keeps everything else going - a vast springboard-cum-safety net spread beneath the formal economy'. However, unpaid work is not counted in the country's economic statistics. In 1988 economist Marilyn Waring commented that 'women and children count for nothing' because their contribution to the economy is not included in official statistics. In the early 2000s women still did the greater share of unpaid domestic work. A national Time Use Survey, conducted in 1998-99 for the Ministry of Women's Affairs found that although men and women spent the same amount of time working, women spent two more hours a day doing unpaid work, and men spent two more hours a day in paid work all over the world. The 2006 census found that women were still more likely than men to do unpaid work. So GDP is under estimated due to unpaid work. It is indeed the case that $66 \%$ of female activities in developing countries are not captured by SNA (compared to only $24 \%$ of male activities, UNDP, 1995: 89), then rise in the productivity of female economic activities may not be recorded at all, or only to an insufficient degree (Waring, 1988). That's why economic growth is undervalued. We do not get the actual scenario of the economy. Further women are basically works for their bear subsistence. So these works are not counted in national income accounting.

Furthermore women are the vulnerable part of the country. They experience hunger and poverty more intense way compared to men. So that any improvement in their situation via labour force participation can have an impact on breaking vicious circle of poverty. That's why they are crowded in the lower paying sector where price elastic goods are produced. So they have very small contribution to the growth of the country and we get a negative impact of this female male ratio in labour force participation on economic growth.

\section{Openness}

Result shows that openness has significantly positive impact on economic growth. It is an indicator of regional dummy which indicates the level of liberalization. According to the result liberalization positively affects economic growth. 


\section{Anova}

It is used to check the overall significance of the model. Table-6 implies that calculated values of $\mathrm{F}$ are higher than the tabulated values. That's why null hypothesis is rejected and alternative hypothesis is accepted that is there is over all significance of estimated model and all the variables used in the model are relevant variables for the study.

\section{References}

[1]. Çagatay, N. and Ozler, S. (1995), Feminization of the Labor Force: The Effects of Long-Term Development and Structural Adjustment, World Development Vol. 23, No.11, pp.1883-1894.

[2]. Fatima, G. (2010), Female Education as a Determinant of Economic Growth- A Case Study of Pakistan, International Conference of Applied Economics.

[3]. Forsythe, N. and Korzeniewicz, R. P. (2000), Gender Inequality and Economic Growth: A Longitudinal Evaluation, Economic Development and Cultural Change, Vol. 28, No. 3, pp. 573-617.

[4]. Klasen, S. (2000), Does Gender Inequality Reduce Growth and Development? Evidence from Cross-Country Regressions, Sonderforschungsbereich 386, Paper 212 .

[5]. Klasen, S. (2002), Low Schooling for Girls, Slower Growth for All? Cross Country Evidence on the Effect of Gender Inequality in Education on Economic Development, The World bank economic review, Vol. 16, No. 3, pp. 345-373.

[6]. Klasen, S. and Lamanna, F. (2003). 'The Impact of Gender Inequality in Education and Employment on Economic Growth in the Middle East and North Africa’, background paper for Gender and Development in the Middle East and North Africa, World Bank: Washington DC.

[7]. Lagerlöf, N. 1999. 'Gender Inequality, Fertility, and Growth'. Mimeographed. Department of Economics, University of Sydney.

[8]. Rasouli, Z. (2013). Economic growth \& Gender inequality in India

[9]. Seguino, S. (2000), Gender Inequality and Economic Growth: A Cross Country Analysis, World Development, Vol. 28, No. 7, pp. 1211-1230

[10]. Todaro, M. P. (2007), Economic development Waring, M. (1988), If Women Counted, New York, Harper and Row World Bank (2012), World Development Indicators, Washington DC, the World Bank. 